Journal Indonesian Language Education and Literature Vol. 2, No. 2, 2017

http://www.syekhnurjati.ac.id/jurnal/index.php/jeill/

\title{
MODEL PENEMUAN KONSEP BERBASIS TEKS PADA PEMBELAJARAN SASTRA
}

\author{
Nazla Maharani Umaya \\ Universitas PGRI Semarang \\ nazlamaharani@upgris.ac.id
}

\begin{abstract}
Abstrak
Salah satu materi dalam pembelajaran bahasa Indonesia adalah sastra. Keberhasilan pembelajaran sastra di SMP perlu ditinjau ulang, terutama di Kota Semarang, Indonesia. Pembelajaran hendaknya memenuhi kebutuhan siswa. Anak berusia 12-15 tahun memiliki karakter dominan pada unsur intelegensi, kepraktisan, kepekaan, dan sikap memilih. Penelitian ini bertujuan untuk memberi alternatif bahan ajar pada pembelajaran sastra. Penelitian ini berdesain deskriptif eksplanatif. Data dikumpulkan melalui analisis dokumen, yakni analisis pada teks dan konsep model aplikasi model. Berdasarkan analisis yang telah dilakukan, dapat dibuktikan bahwa pembelajaran berbasis teks dapat menjadi alternatif model pembelajaran sastra. Kelebihan bahan ajar ini adalah dapat mencapai tujuan belajar serta dapat menemukan konsep dan menentukan keputusan dalam bersikap secara sosial. Oleh karena itu, teks sastra realis dapat dimanfaatkan sebagai sumber dan bahan ajar.
\end{abstract}

Kata kunci: Indonesia, karakter, pembelajaran, realisme, sastra

\begin{abstract}
One learning Indonesian hearts material is literary. Learning success in junior high literature should be reviewed, especially in Semarang, Indonesia. Learning should fulfill student needs. Child with 12-15 year olds have the character of a dominant element on intelligence, practicality, sensitivity, and attitude vote. This research aims to review the alternative providing learning materials with open literature. This research desaign use descriptive explanative. Data were collected through document analysis, the analysis of text and model at application concept model. Based on the analysis can be proved that the text-based learning can be an alternative become learning model literature. Excess teaching materials literature is can be achieve the learning objectives as well as can be found the concept and determine the decision hearts operating be social. So, text realist literature can be utilized as a source and teaching materials.
\end{abstract}

Keywords: characters, Indonesia, learning, literature, realism

\section{A. Pendahuluan}

Aktivitas mempelajari seluruh aspek kehidupan melalui imajinasi terakomodasi melalui pembelajaran sastra. Di sekolah menengah pertama (SMP), hal tersebut merupakan bagian mata pelajaran bahasa Indonesia. Karya sastra yang tercakup dalam mata pelajaran, meliputi: puisi, drama, dan prosa pendek. Kegiatan dapat berlangsung di 


\section{Journal Indonesian Language Education and Literature Vol. 2, No. 2, 2017 \\ http://www.syekhnurjati.ac.id/jurnal/index.php/jeill/}

dalam dan di luar kelas dengan berbagai kendala. Konteks pembahasan kali ini adalah pada pembelajaran di dalam kelas. Kendala yang kerap ditemui cukup bervariasi. Faktor yang berpengaruh adalah: (1) penggunaan pandangan, pendekatan, dan metode pengajaran yang hanya bersifat verbal dan teori serta (2) minim dalam menciptakan peluang siswa memiliki pengalaman apresiasi dan berkreasi di bidang sastra (Simaremare, 2010: 7). Hasil observasi di beberapa sekolah di Kota Semarang ditemukan kendala pada penggunaan durasi waktu penuntasan pembelajaran. Antara waktu yang tersedia dengan kuantitas konten yang dipelajari (termasuk pemilihan teks materi tambahan) tidak berimbang. Model dan penggunaan perangkat pilihan menentukan kondisi menjadi lebih baik atau sebaliknya. Pembelajaran sastra berciri khas memiliki kedekatan dengan proses menggali ide dan kreativitas. Hal yang diterima siswa apabila tidak memudahkan untuk menuntaskan pembelajaran justru akan menghambat pengembangan kemampuan. Pilihan model belajar yang kurang tepat dapat menyebabkan kebingungan pada siswa. Pada situasi yang demikian, kerap memunculkan tindakan spontan oleh guru dalam membimbing siswa dan mengakibatkan pembelajaran tidak terarah.

Peran inti dalam aktivitas pembelajaran adalah pengajar, perangkat, serta tindakan pembelajaran yang menyesuaikan karakter pembelajar. Pendidikan di sekolah smerupakan sarana membangun logika pada anak. Hasilnya dapat berupa taat aturan pada kegiatan pembelajaran, melibatkan logika berpikir, adanya penerimaan sebagai pemahaman, dan bukan kegiatan meniru (Peters, 2010: 123). Hal tersebut adalah kunci utama keberhasilan pembelajaran. Hal yang diterapkan dalam kelas akan mencapai tahap aplikasi apabila pelaku mampu menerima pengetahuan yang diperoleh pada tataran logikanya. Satu lagi permasalahan besar lainnya dalam pembelajaran sastra adalah terkait penetrasi media. Dalam aktivitas sosial, pelajar dipengaruhi oleh kemandirian menggali pengetahuan yang berujung pada kadar kesadaran berbahasa, potensi individual, dan kebebasan berkreasi (Liliani, 2012: 164). Permasalahan tersebut terindikasi pada beberapa buku sekolah elektronik pelajaran bahasa Indonesia di SMP. Buku tersebut berkesan membatasi, yaitu hanya pada ketentuan yang tertulis secara kaku. Berikut simpulan sementara dari contoh konten dalam materi cerita fantasi untuk anak, yaitu mayoritas pada cerita bertokoh anak, cerita fabel hanya cerita mengenai 
hewan legendaris seperti kancil, naga, serigala, dan kura-kura, serta jenis cerita yang hanya mencakup kehidupan dunia anak.

Rancangan pembelajaran berfungsi sebagai sistem pengikat dalam pelaksanaan pembelajaran. Pembelajaran kontekstual yang dapat membentuk kemampuan pada siswa untuk mengatur dirinya sendiri (Moos \& Ringdal, 2012: 5) pada idealnya akan terikat pada konteks budaya dan sosial masyarakat sekitar.. Kompetensi awal yang dimiliki siswa menjembatani penalaran siswa terhadap pengetahuan baru melalui penalaran konkret. Mempelajari karya sastra daerah, bagi siswa memerlukan landasan konsep yang matang untuk memetakan logika selama proses pemahaman berlangsung. Demikian pula konsep pemahaman yang mendasar di tempat berbeda. Penguat pernyataan tersebut adalah keterkaitan antara perangkat penunjang dalam proses belajar memiliki tujuan untuk memenuhi kebutuhan siswa (Cunningsworth, 2008: 7). Oleh karena itu, dibutuhkan penghubung untuk menyatukan antara kompetensi dasar yang telah dimiliki siswa dengan kompetensi inti yang tertera pada rancangan.

\section{B. Metode Penelitian}

Metode analisis penelitian ini menggunakan analisis pustaka (Moleong, 2010: 11). Metode tersebut juga dipergunakan dalam analisis konten buku pelajaran yang dipergunakan secara universal untuk pembelajaran sastra di SMP. Digunakannya buku sekolah elektronik untuk menemukan celah penerapan model tersebut dan perancangan aplikasinya. Luaran penelitian berupa alur sistematika proses pengembangan model penemuan konsep dalam pembelajaran sastra. Pemetaan disesuaikan antara konsep hasil rancangan pengembangan dengan standar nasional pendidikan yang berlaku. Adapun langkah-langkah pelaksanaan penelitian dan aplikasi perancangan pengembangan model, meliputi: 1) analisis teks sastra secara objektif dengan konteks sesuai tujuan pembelajaran, 2) analisis konten buku pelajaran bahasa Indonesia SMP pada setiap jenjang tingkatan, 3) analisis rancangan model penemuan konsep dan transformasinya ke dalam aktivitas pembelajaran sastra, serta 4) analisis konten pada hasil rancangan dengan memetakan komponen pada dokumen standar pendidikan nasional, yaitu kurikulum, standar kompetensi, serta standar pelaksanaan pendidikan. Hasil penelitian berupa pengembangan model penemuan konsep dalam pembelajaran sastra yang dapat diaplikasikan dalam pembelajaran untuk siswa SMP. 


\section{Hasil dan Pembahasan}

Perolehan hasil analisis terhadap konten dan konteks menjadi data dasar penelitian ini. Sudut pandang dalam menentukan objek atau teks pilihan adalah siswa SMP dan genre teks berupa prosa. Objek yang dituju adalah teks sastra prosa pada buku siswa terbitan versi kurikulum 2013 edisi revisi tahun 2016. Teks sastra dalam buku siswa ditemukan empat kategori teks yang terdiri atas teks sastra berupa bagian dari novel, teks cerita tidak bersumber, teks cerita hasil adaptasi, dan teks cerita dari media massa. Konteks pembelajaran yang tercatat adalah memahami dan mencipta cerita fantasi, serta mengapresiasi dan mengkreasi fabel. Konten dominan dari seluruh teks tersebut adalah mengenai pertarungan di dunia hewan, perjalanan dengan banyak peristiwa, dan petualangan singkat di dunia lain, manajemen waktu, persaudaraan, pertemanan, dan kejujuran.

Peran cerita fantasi pada buku siswa menjadi hal penting dalam rangka pengetahuan berkreativitas. Berfantasi secara aktif dapat mengasah kemampuan beranalogi dan menentukan simpulan bagian akhir sebagai wujud keputusan. Cerita fantasi seperti dongeng merupakan cerita suatu kejadian yang tidak sungguh-sungguh pernah terjadi, maka analogi yang pertama muncul adalah imajinasi dan rekaan. Kedekatan antara konten dengan pembaca mempengaruhi jangkauan imajinasi dan rekaan. Apabila hal tersebut berlanjut pada aktivitas baru, atau memiliki koneksi hanya secara konteks, maka kendala yang dihadapi adalah proses transformasi dari pengetahuan dalam imajinasi menjadi pengetahuan dalam kehidupan nyata mengalami pergeseran intepretasi dan proses pembelajaran tidak berdampak maksimal. Salah satu sampel hasil temuan adalah pada konteks pembelajaran "Mengidentifikasi karakteristik unsur pembangun cerita fantasi”. Tujuan pembelajaran yang direncanakan dapat diidentifikasi melalui kotak info. Fungsi lainnya adalah kontak info sebagai bentuk konfirmasi guru terhadap proses pembelajaran yang telah dilaksanakan siswa, diletakkan pada bagian akhir.

Kotak info dan tujuan pada konteks pembelajaran menggunakan teks tersebut adalah siswa mengetahui ciri umum teks narasi mencakup definisi narasi; definisi alur; hukum rangkaian peristiwa berupa sebab akibat; tahap penceritaan yang terdiri dari pengenalan, pertentangan, dan penyelesaian; tokoh dan watak tokoh sebagai unsur cerita; definisi dan perumusan menentukan tema cerita; dan amanat. Hal berikutnya 


\section{Journal Indonesian Language Education and Literature Vol. 2, No. 2, 2017 \\ http://www.syekhnurjati.ac.id/jurnal/index.php/jeill/}

adalah siswa mengetahui ciri umum cerita fantasi yang mencakup adanya unsur supranatural, kemisteriusan, keghaiban, dan tidak ditemui dalam dunia nyata; definisi cerita fantasi; tokoh tidak ada dalam dunia nyata atau hasil modifikasi penulis; tema fantasi adalah magis, supernatural atau futuristik; ide cerita bersifat khayalan penulis, tidak dibatasi fakta; penggunaan latar lintas ruang dan waktu; adanya tokoh unik dengan kesaktian; dan bersifat fiksi atau fiktif. Seluruh kontek dalam kotak info tersebut menjadi jangkauan siswa setelah berkegiatan dan berhasil apabila mampu menjangkau konten teks. Jenis aktivitas dan proses kegiatan menjadi penghubung antara konteks dengan konten teks. Hasil analisis diperoleh adanya fungsi konten yang terbuang dan tidak mendukung proses penjangkauan oleh siswa dikarenakan aktivitas belajar yang kurang sesuai. Berikut dalam bentuk skema.

\section{Aktivitas melibatkan konten}

Membaca dan menuliskan rangkaian peristiwa untuk menemukan ragam jenis sumber teks cerita fantasi

Menuliskan keajaiban tokoh dan peristiwa

Menuliskan latar dalam cerita (latar waktu)

Menuliskan alasan dan bukti yang menunjukkan jenis latar, jenis cerita fantasi

Mendiskusikan ciri alur dan latar cerita

Menyimpulkan ciri umum cerita fantasi

\section{Kotak Info (Konfirmasi guru)/ Konteks}

Definisi cerita fiksi sebagai narasi hasil pengembangan kejadian dan alur.

Hukum cerita fantasi yaitu sebab akibat

Tahap dalam cerita yaitu pengenalan, pertentangan, dan penyelesaian

Tokoh dan perwatakannya

Tema narasi

Definisi amanat

Ciri umum cerita (terdapat uncur keajaiban, supranatural)

Hal dalam cerita fantasi adalah hal yang tidak ada di dunia nyata, mencakup tokoh unik, dan bersifat fiktif.

? (terjadi kehilangan fungsi konten)

\section{Gambar 1.}

\section{Skema Penggunaan Fungsi Konten dan Konteks dalam Aktivitas Belajar Sastra}

Visualisasi pada gambar tersebut adalah penggambaran situasi konten teks sastra tidak terjangkau untuk mendukung siswa mencapai konteks pembelajaran. Perbandingannya adalah dari enam butir aktivitas, terdapat empat jenis aktivitas yang menghilangkan fungsi konten. Seperti pada butir aktivitas kedua, menuliskan keajaiban tokoh dan peristiwa berdasarkan petunjuk dan instruksi pada buku siswa berupa aktivitas tokoh dan peristiwa yang dialami tokoh. Maka transformasi perolehan hasil belajar mengarah pada tokoh, keahlian tokoh, keunikan tokoh, serta peristiwa nyata dan tidak nyata. Jika dikaitkan dengan konteks maka perolehan pengetahuan siswa melalui konten tidak berfungsi secara tepat. Hal ini disebabkan kekurangtepatan dalam 


\section{Journal Indonesian Language Education and Literature Vol. 2, No. 2, 2017 \\ http://www.syekhnurjati.ac.id/jurnal/index.php/jeill/}

mengenal tokoh, selain unik, tokoh juga memiliki perwatakan tersendiri (karakteristik kepribadian). Petunjuk dan instruksi yang tidak mengakomodasi konten menyebabkan pelebaran hasil analogi pada siswa sehingga tidak mengarah pada konteks, yaitu apa yang harus diperoleh siswa setelah melakukan pembelajaran tersebut. Konteks bahwa membaca teks sastra untuk mengetahui hukum cerita fantasi yang memiliki sifat rangkaian peristiwa berupa sebab akibat tidak terjangkau. Demikian pula konteks berkait pengetahuan mengenai tahap dalam cerita yang terdiri dari pengenalan, pertentangan, dan penyelesaian tidak terjangkau hanya dengan menuliskan rangkaian peristiwa yang terdapat satu tokoh (Nataga) tanpa melibatkan tokoh yang lain (serigala, dewi kabut, semut, dan tokoh lainnya) yang berada dalam satu cerita. Terjadinya penghilangan fungsi konten disebabkan oleh jenis petunjuk dan instruksi kerja atau kegiatan belajar yang tidak menyesuaikan konten teks sastra yang dipergunakan.

Hal-hal dalam karya sastra yang telah dipilih dapat dipergunakan sebagai data pembangun analogi pada siswa bahwa kategori teks sastra dapat ditentukan berdasarkan pada aspek konten teks. Penggunaan unsur pembangun cerita termasuk penggunaan nama-nama tokoh mengidentifikasikan perbedaan antara cerita fantasi utuh dengan cerita fantasi ilmiah. Konten berupa penggunaan nama jenis hewan sebagai nama tokoh adalah ilmiah apabila sesuai dengan karakter yang terbukti secara keilmuan, tetapi menyajikan tokoh hewan dengan perwatakan dan karakter seperti manusia merupakan fantasi yang utuh. Pilihan teks-teks tersebut dan hasil analisis strukturnya harus disesuaikan dengan standar ketentuan belajar, salah satunya adalah memberikan pengetahuan, pengalaman, serta keahlian lain sesuai kompetensi inti yang disarankan. Jenis komponen lainnya yang dapat dikoneksi dengan teks adalah pada instruksi dan petunjuk kegiatan belajar (sikap dan aktivitas sosial). Hal tersebut dilakukan menggunakan teknik transformasi konten teks. Tema teks tersebut adalah peristiwa kehidupan (yang diperankan oleh hewan) sehingga masih memiliki aspek interaksi, aktivitas bersama, dan komunikasi. Penggunaan setting dengan penyajian dari aspek beragam pada teks menjadi sumber data, informasi, dan pengetahuan bagi pembaca cerita (siswa) mengenai aktivitas kontra fakta yang beranjak dari fakta, serta pembangunan imajinasi sebagian dan imajinasi murni. Beberapa unsur dalam teks tidak terbangun secara pragmatis karena hanya merupakan bagian cerita (tidak utuh) dan disajikan dengan teknik yang memungkinkan terjadinya pemangkasan konten. Situasi 
demikian banyak ditemukan dan memerlukan perlakuan tambahan untuk dapat memfungsikan teks sesuai kebutuhan siswa dan rencana tujuan pembelajaran.

Pembahasan selanjutnya adalah hasil perancangan konsep mengkoneksi antara konten dan konteks, antara teks sastra (pilihan) dan pembelajaran. Informasi penggunaan perangkat pendukung pembelajaran yang ditemukan pada observasi adalah dominasi penggunaan buku paket dan bahan belajar universal. Pilihan teks sastra yang dipergunakan berupa kutipan novel, cerita bebas (tanpa sumber), adaptasi cerita hewan atau fabel (parafrasa), cerita pendek (karya yang dipublikasi media massa), dan dongeng hewan (karya yang dipublikasi media massa). Beberapa ketidaksesuaian dari jenis teks pilihan dalam pembelajaran sastra adalah menggunakan kutipan novel untuk mengajarkan teks sastra (utuh), mulai dari memahami ciri dan karakter, mengembangkan pengetahuan, mengekspresikan ide dan kreativitas, serta mencipta. Ketidaksesuaian yang kedua adalah penggunaan pilihan teks tanpa sumber (bebas). Kedua hal tersebut berkemungkinan besar mempengaruhi siswa dalam menerima pengetahuan yang tidak konkret. Petunjuk kegiatan yang telah runtut menjadi panduan aktivitas yang berujung pada kemampuan verbal dan teoretis saja. Aktivitas imajinasi dalam pembelajaran sastra memiliki tujuan pada pemberian alternatif imajinasi terhadap realitas. Proses imajinasi merupakan tindakan yang menandakan pikiran manusia berada pada satu perbatasan terakhir dari pikirannya dan kemudian menciptakan alternatif kontra fakta dengan realitas yang ada dalam kehidupan sehari-harinya yang memicu aktivitas penciptaan alternatif yang memberikan rasa kepastian mengenai peristiwa atau perasaan mengenai hal lain yang ditangkapnya dalam fakta. Dengan demikian, imajinasi utuh memberikan hasil berbeda apabila dibandingkan dengan proses pembangun imajinasi sebagian.

Bentuk lainnya yang dapat dipertimbangkan adalah penyempurnaan pengantar aktivitas belajar (seperti yang telah disampaikan pada bagian sebelum dalam artikel ini), menghadirkan materi berbasis teks yang mampu membentuk penemuan konsep dan kematangan pemahaman sebagai dasar untuk memulai pembelajaran pokok yang berkaitan dengan teks dan materi tujuan. Aktivitas dirancang untuk membangun persepsi yang beranjak dari temuan konsep mengenai teks cerita dan teks sastra. Fungsi petunjuk dan instruksi belajar dalam perangkat belajar adalah sebagai medium komunikasi antara pengajar, teks, dan pembelajar. Penghadiran teks pengantar dengan 
model penemuan konsep, bertujuan memberikan informasi dan esensi dalam teks kepada siswa untuk bekal pembangun konsep, tahap aktivitas pembangunan konsep harus berada dalam jalur proses bertahap. Dengan demikian petunjuk dan instruksi menjadi kunci keberhasilan proses belajar dan pemahaman. Dengan pertimbangan hal tersebut, maka keselarasan, kesesuaian, dan ketepatan penyajian materi dan aktivitas memahami teks beranjak dari teks materi yang sama. Dasar konsep penentuan pilihan kata kerja operasional seperti teori Bloom, dipergunakan dalam proses pembentukan petunjuk dan instruksi lengkap. Berikut skema konsep pembentukan petunjuk dan instruksi yang ditawarkan dengan perbandingannya pada materi yang ada.

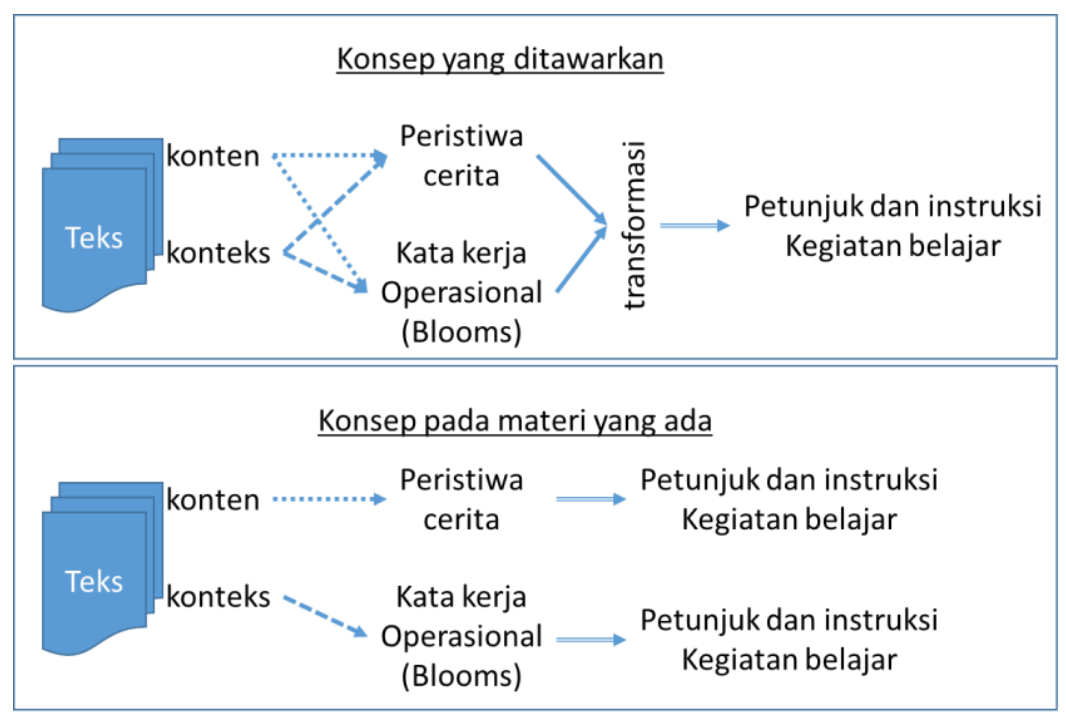

\section{Gambar 2. \\ Perbandingan Konsep Pembentukan Petunjuk dan Instruksi Kegiatan Belajar Berdasarkan Hasil Analisis Konten}

Materi belajar dan kelengkapan petunjuk serta instruksi kegiatan dalam satu proses belajar menjadi komponen penting yang saling mendukung aktivitas untuk pencapaian tujuan belajar oleh siswa. Konteks pembelajaran yang menjadi contoh (pada materi belajar dalam buku siswa versi kurikulum 2013 edisi revisi 2016), adalah dua buah teks cerita disajikan untuk pembelajaran mengidentifikasi unsur cerita fantasi (tokoh, tema, setting, keajaiban, hal istimewa, alur), yang secara konseptual memiliki unsur yang sama dengan jenis cerita lainnya. Penekanan fantasi pada unsur adanya kontra fakta telah ditentukan tanpa adanya proses pembangunan dan penemuan konsep oleh siswa. Aktivitas yang terbentuk adalah proses mengingat (hasil pembacaan teks 


\section{Journal Indonesian Language Education and Literature Vol. 2, No. 2, 2017 \\ http://www.syekhnurjati.ac.id/jurnal/index.php/jeill/}

untuk dituliskan kembali), menulis ulang (menyampaikan hasil temuan yang berkaitan dengan kata kunci), dan mencocokkan bagian (yang telah tersedia dan ditentukan). Petunjuk dan instruksi dalam kegiatan melalui penggunaan materi belajar tersebut (yang digunakan) menanamkan konsep yang terbentuk oleh guru atau si pembuat buku dengan keputusan telah ditentukan, pada bagian akhir pembelajaran tertulis "jadi sumber cerita fantasi dapat berupa kondisi nyata yang difantasikan" tertera dalam rangkaian materi.

Aktivitas dapat mengalami pelebaran, antara tujuan yang telah dirancang dengan capaian yang diperoleh setelah pembelajaran. Penggunaan perangkat untuk mencapai tujuan pembelajaran dan jenis perangkat yang baik adalah yang berkedudukan sebagai sumber daya dalam mencapai tujuan dan sasaran pembelajaran. Hal itu sesuai dengan kebutuhan siswa dan diarahkan pada capaian yang diperoleh siswa. Secara tidak langsung kesesuaian tersebut dapat memenuhi tujuh hal utama dalam aktivitas pendidikan, yaitu bersifat mendidik, memiliki ketentuan hal yang dipelajari dan alasan mempelajari, dilakukan dengan cara dan sebuah proses, menggunakan pendekatan yang sesuai, tercakup kriteria yang dapat mengubah pengetahuan menjadi aktivitas belajar, adanya konsep dan teori yang dipelajari, dan tersedianya peluang eksplorasi dan berproses bagi siswa (pembelajar), salah satunya adalah menemukan konsep berdasarkan hasil memahami yang dipelajarinya. Berikut adalah hasil perolehan setelah dilakukan pencermatan dan analisis konten. Teridentifikasi adanya aktivitas yang melebar sebagai berikut.

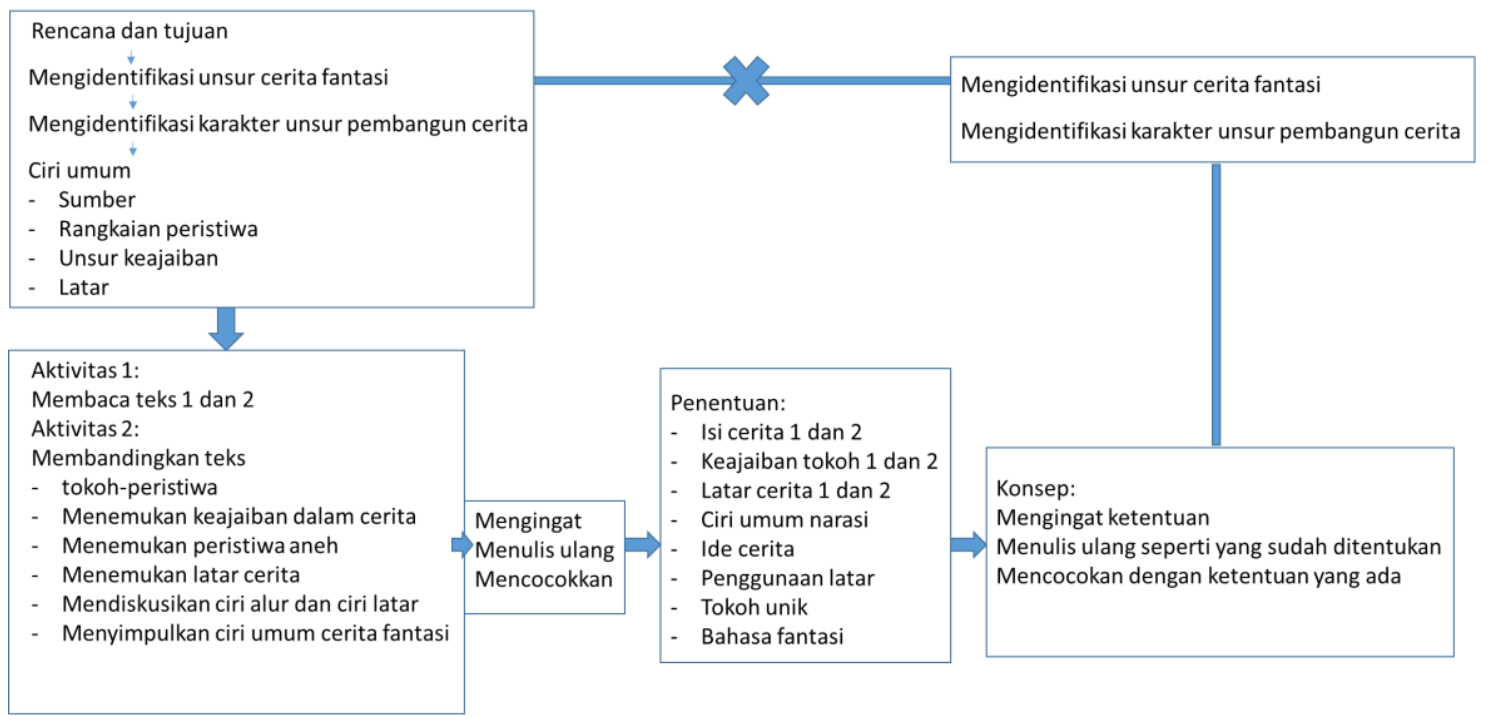

Gambar 3.

Ilustrasi Aktivitas Belajar Berdasarkan Materi dan Buku Siswa yang Digunakan 


\section{Journal Indonesian Language Education and Literature Vol. 2, No. 2, 2017 http://www.syekhnurjati.ac.id/jurnal/index.php/jeill/}

Pada gambar 2, pelebaran aktivitas terjadi saat pascaproses memahami materi yang dilakukan siswa dengan membaca teks. Pada awal aktivitas membaca, telah ditemukan petunjuk dan instruksi yang mengarahkan pembangunan analogi siswa saat proses membaca pada tujuan awal pembelajaran, yaitu mengidentifikasi karakter unsur pembangun cerita fantasi yang diawali dengan menemukan alasan sebuah cerita dikatakan sebagai cerita fantasi. Adapun yang terjadi adalah adanya pertentangan antara ilustrasi aktivitas dengan konsep yang pernah disampaikan. Pengembangan bahan ajar harus memiliki keterkaitan dengan lingkungan sosial pembelajar dan bersifat berkelanjutan. Begitupun dengan pemikiran ahli pendidikan, bahwa apabila program pendidikan tidak menerapkan prinsip dasar dalam perencaan program pendidikan karakter, maka tidak mampu mengembangkan kemampuan siswa dalam meningkatkan motivasi belajar.

Aktivitas lanjutan yang dihasilkan adalah terbentuk konsep yang mengarah pada "teacher center" yang melebar secara halus, dan kemampuan mengidentifikasi yang diperoleh siswa tidak beranjak dari pembangun konsep dari analogi pemikiran siswa, tujuan tidak tercapai. Pembelajaran yang demikian berhadapan dengan karakter siswa pada usia tersebut (unsur intelegensi, kepraktisan, kepekaan, dan sikap memilih untuk dirinya) berakhir dalam kondisi intelegensi yang tidak bergerak bebas, kepraktisan yang memiliki kecenderungan sebagai kepribadian "pengikut" dan bukan "inovator", serta sikap memilih untuk dirinya melebar menjadikan sasaran hanya pada hal-hal yang bersifat verbal dan teoritis. Ragam variasi karya sastra yang terus menjamur menjadi kesulitan yang tidak pernah terselesaikan dalam permasalahan siswa pada pembelajaran sastra khususnya, dan bahasa Indonesia pada umumnya.

Beberapa penjelasan tersebut mengarah pada penggunaan model penemuan konsep yang telah dikembangkan secara aplikatif dengan salah satu metode berupa transformasi teks ke dalam aktivitas pembelajaran sastra yang dibahas selnajutnya berikut ini. Pembelajaran sastra dapat dikatakan sebagai salah satu pembelajaran yang penuh dengan aktivitas pemerolehan informasi yang dilanjutkan dengan pemrosesan informasi yang diperoleh, hingga dihadapkan dengan pilihan dan pengambilan keputusan yang melibatkan kapasitas intelektual dan pengembangan. Aktivitas capaian dominan adalah pada kreativitas yang diekspresikan dan terus mengalami peningkatan sepanjang proses terus belangsung dan berkelanjutan. 


\section{Journal Indonesian Language Education and Literature Vol. 2, No. 2, 2017 http://www.syekhnurjati.ac.id/jurnal/index.php/jeill/}

Dalam pembelajaran sastra dengan konsep model menemukan konsep dapat dikolaborasikan dengan aktvitas berpikir induktif. Aktivitas melibatkan proses berpikir diawali dari tindakan identifikasi, pengelompokan yang mampu membangun konsep dan intepretasi hingga mencapat kesimpulan disebut dengan aktivitas induktif. Sumber informasi diperoleh dari sebanyak-banyaknya sumber sesuai dengan rencana, pelaksanaan, dan target waktu pencapaian. Perolehan aktivitas tersebut menjadi suatu prinsip yang selanjutnya dapat diterapkan pada situasi berbeda dengan karakteristik yang serupa atau sama. Dalam proses pembelajaran, aktivitas demikian mampu menjadi proses bertahap dalam mengembangkan kompetensi. Penjelasan tersebut mendekatkan pada pemahaman model pembelajaran penemuan konsep.

Salah satu sampel materi dalam pembelajaran sastra adalah mengidentifikasi unsur cerita fantasi. Hal dasar dalam proses belajar tersebut adalah menemukan dasar konsep penentuan kategori untuk cerita fantasi. Secara mimetis, karya sastra dapat dianggap sebagai tiruan kehidupan. Oleh karena itu, pijakan awal dalam proses intepretasi adalah ada dan tidaknya koneksi antara hal yang ditemukan dalam kehidupan dengan yang tertera dalam karya sastra. Secara objektif, bangunan dalam karya sastra disepakati terbangun oleh unsur-unsur dan menimbulkan anggapan bahwa karya sastra dapat dimaknai berdasar sesuatu yang tertera dalam karya tersebut.

Dua dari empat jenis pendekatan dalam memahami karya sastra tersebut merupakan pembatasan fokus pembahasan kali ini. Segala yang tercakup dalam karya sastra berkait dengan kehidupan dan bisa dilepaskan dari kehidupan. Cerita fantasi tidak memilih dari keduanya, tetapi menggabungkan dari kedua hal tersebut. Konten akan berkait dengan kehidupan, dan unsur kehidupan dalam karya sastra adalah versi pengarang dan kebebasannya dalam menentukan pilihan unsur. Beranjak dari hal-hal tersebut, berpikir induktif dalam pembelajaran sastra dapat memanfaatkan pandangan secara objektif untuk menemukan informasi dalam cerita, dan memanfaatkan sifat tiruannya untuk mengkategori komponen dalam karya sastra.

Informasi yang diberikan disampaikan menggunakan medium teks sastra. Terbukti atau tidak terbukti bahwasanya karya tersebut memiliki komponen yang dekat dengan hal nyata dalam kehidupan. Seperti halnya adanya penggunaan istilah "pasukan siluman serigala" dalam cerita, maka kata "pasukan dan serigala" mendekatkan intepretasi pada kehidupan nyata (mimetis), dan kata "siluman" yang membatasi 


\section{Journal Indonesian Language Education and Literature Vol. 2, No. 2, 2017 \\ http://www.syekhnurjati.ac.id/jurnal/index.php/jeill/}

intepretasi pada unsur pembangun karya sastra secara objektif (diciptakan dan diputuskan oleh pengarang). Sehingga pemahaman fantasi yang dapat disepakati sebagai adanya komponen kontra fakta tetap beranjak dari kehidupan (nyata) dan dapat dipahami secara konseptual dengan mengembalikannya pada ranah kehidupan nyata.

Dari pernyataan tersebut, aktivitas siswa dalam pembelajaran sastra, memahami karya sastra untuk menemukan konsep dapat diawali dengan mendekatkan segala yang disajikan dalam karya sastra ke dalam kehidupan sekitar pembaca sastra tersebut. Proses berpikir alami akan berawal dari fakta sampai mencapai titik pembatas antara fakta dan kontra fakta akan terbangun pemikiran mengenai definisi fantasi. Maka kumpulan informasi yang memiliki konsep demikian dihadirkan sebagai data pada siswa untuk dilakukan proses identifikasi. Berikut dalam skema, bentuk-bentuk konten teks cerita yang mencakup konsep tersebut.
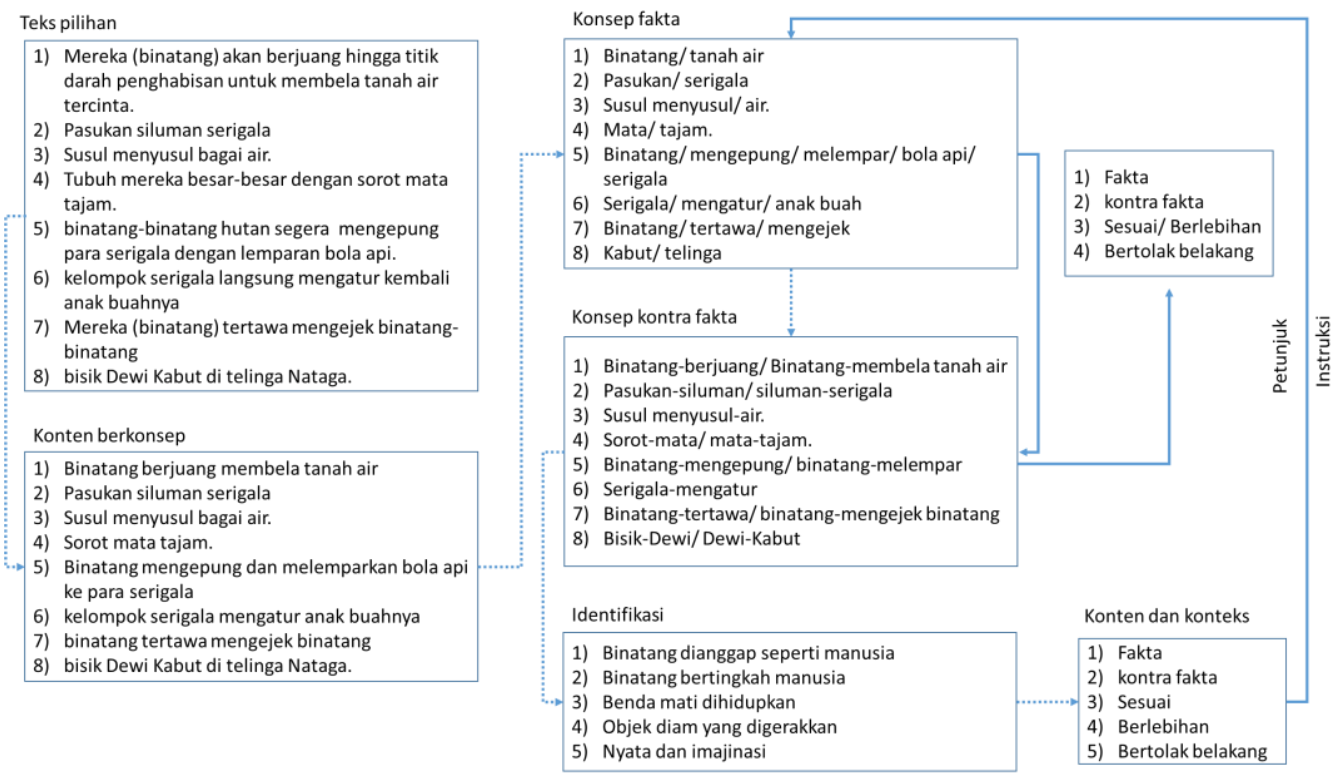

Gambar 4.

Sistematika Penciptaan Petunjuk dan Instruksi Kegiatan serta Aktivitas Berpikir Induktif

Mengarahkan pembelajar pada aktivitas berpikir induktif untuk mampu membangun konsep berdasarkan analogi dan kemampuannya dalam mengidentifikasi dengan hasil sesuai rencana tujuan pencapaian harus dilakukan berdasarkan pemetaan pola berpikir induktif. Hal- hal yang dilakukan adalah pengajar dapat membaca secara berulang dan cermat pada teks untuk menentukan konten isi cerita. Selanjutnya adalah menata konten-konten tersebut hingga menghasilkan konsep pertimbangan jenis 
informasi berupa bagian cerita yang dijadikan data kontra fakta (imajinatif, tidak nyata, tidak sesuai sifat, hadir dengan dilebih-lebihkan). Aktivitas tersebut membangun konsep fakta dan kontra fakta untuk dilakukan identifikasi komponen pada pilihan teks yang dapat diputuskan sebagai unsur fantasi. Dari hasil tersebut diperoleh konten dan konteks yang dipergunakan sebagai penyusunan petunjuk, instruksi kegiatan, dan instrumen sebagai pendukung siswa dalam membangun konsep ciri cerita fantasi (menemukan fakta, kontra fakta, unsur yang sesuai atau berlebihan, serta bertolak belakang) seperti ilustrasi berikut.

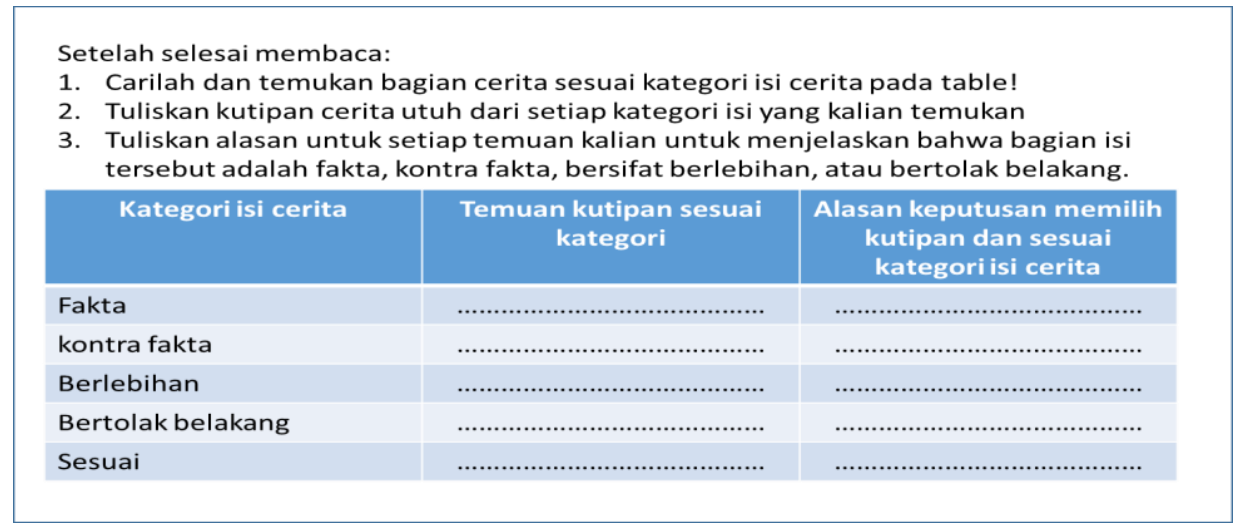

\section{Gambar 5. Hasil Penyusunan Petunjuk dan Instruksi Berdasarkan Analisis Teks}

Temuan dan hasil aktivitas belum dapat membangun konsep bagi siswa secara utuh dan mandiri. Kerap hal tersebut menjadi celah yang oleh guru diselipin keputusan atau ketentuan, sehingga proses pembangunan analogi pada siswa yang belum sempurna menjadi tidak tuntas. Hasil capaiannya akan melebar menjadi kemampuan mencontoh, meniru, dan mengulang apa yang diamatinya, tidak sebagai innovator atau pembangun konsep. Penyempurna aktivitas diperlukan melalui materi atau data analogi pembanding sebagai pertimbangan dalam mengambil keputusan. Seperti penggambaran proses pada skema berikut. 


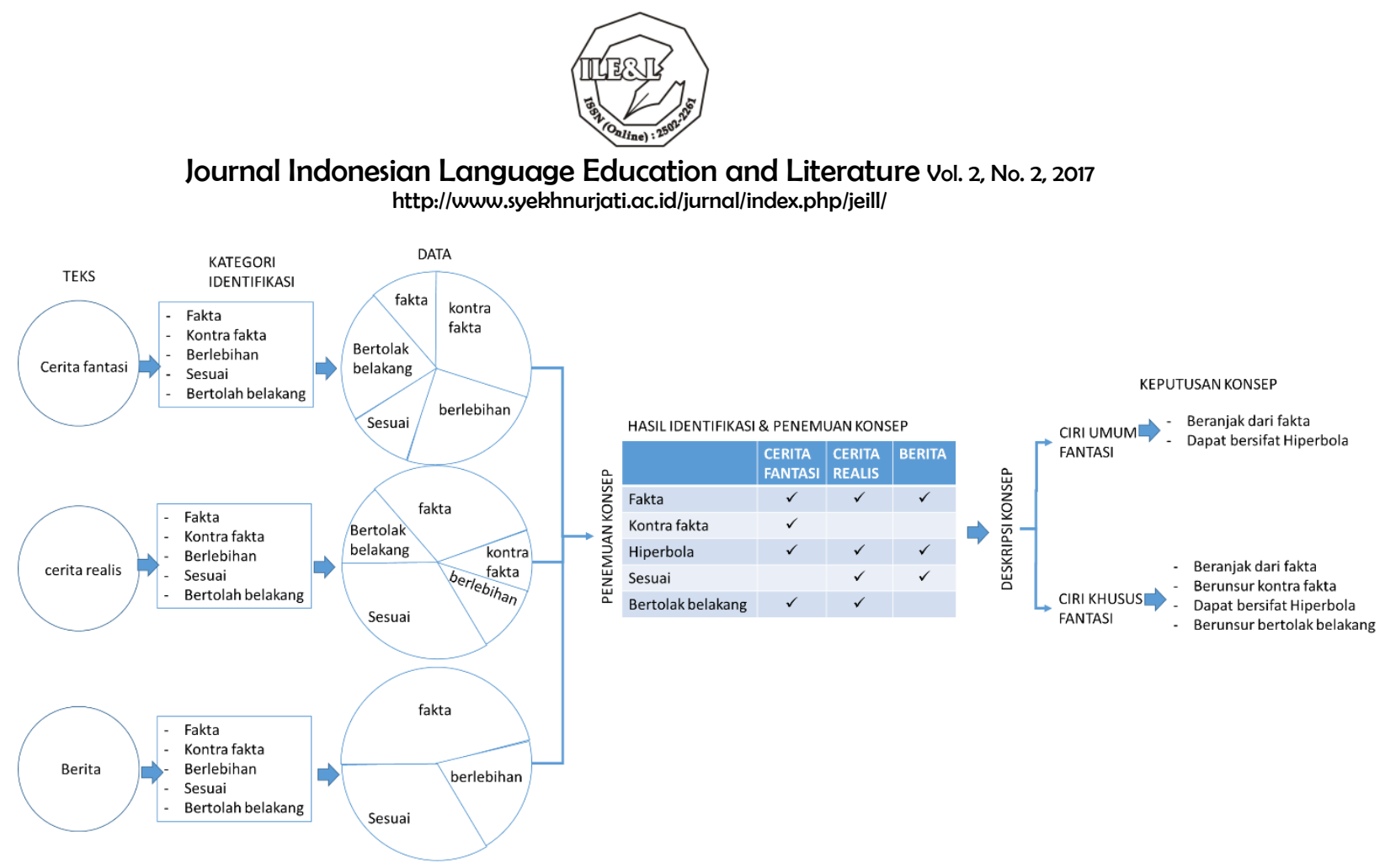

\section{Gambar 6.}

\section{Aktivitas Penuntasan Proses Penemuan Konsep dalam Pembelajaran Sastra}

Menghadirkan teks pembanding dengan teknik penelusuran data yang sama membentuk analogi-analogi dalam ragam karakter dan hasil identifikasi yang dapat membangun konsep sebagai keputusan yang telah ditentukan berdasar pada intelegensi, pemahaman, analogi hasil membandingkan, identifikasi data dan informasi yang ditemukan, dan kesimpulan. Temuan konsep dasar mengenai kriteria atau alasan mengapa sebuah cerita dikatakan sebagai cerita fantasi memberikan dampak pada kemampuan analisis pada pembelajaran di tahap selanjutnya (mengetahui unsur pembangun cerita) sekaligus ciri-ciri yang dimiliki bagi setiap cerita.

Komponen pembangun cerita yang terdiri dari tema, tokoh, alur, setting, dan gaya penceritaan beranjak dari konsep yang telah diperoleh siswa sebelumnya. Data perolehan siswa merupakan hasil pemetaan konsep bahwa ciri umum cerita fantasi terdiri dari, cerita dapat beranjak dari fakta. Maka data dan informasi yang diperoleh siswa pada unsur tema mengarah pada identifikasi bahwa tema dapat beranjak dari fakta atau kontra fakta. Tokoh dapat disajikan dengan apa adanya atau terjadi perlakuan hiperbolis, dan sesuai atau bertolak belakang. Dan yang pasti adalah bahwa dalam cerita fantasi tidak ditemukan tokoh yang sesuai dengan realita dan kenyataan.

Hasil identifikasi lanjutan konsep tersebut memberikan pengembangan pengetahuan mengenai ragam aspek fantasi yang ditemukan pada tiap unsur pembangun cerita. Tema yang beranjak dari fakta, dikarenakan adanya proses penghadiran unsur 
kontra fakta memberikan tema yang bersifat hiperbola, memiliki unsur ketidaksesuaian dengan realitas, atau dihadirkan dengan tampilan yang bertolak belakang dari realita. Tema cerita fantasi "Kekuatan Ekor Biru Nagata" memiliki aspek fakta dalam cerita, seperti halnya penghadiran setting tempat pulau komodo (realitas), pilihan tokoh cerita berupa ragam hewan (realitas), dan penggunaan setting waktu yang terdiri dari siang dan malam (realitas).

Unsur tersebut dilengkapi dengan aspek fantasi yang bersifat hiperbola, seperti halnya pada pulau Komodo yang dihadirkan sebagai tanah airnya para hewan, tokoh serigala yang memiliki kemampuan dan berperilaku seperti manusia, benda mati seperti kabut yang dapat berbisik seperti manusia, dan api biru yang dipaparkan melingkar dapat mengalahkan sekelompok serigala besar, liar, dan kuat. Data dan informasi tersebut membangun analogi pembanding pada proses penalaran yang mengarah pada adanya unsur kesesuaian, hal yang bersifat bertolak belakang, hiperbola, dan mulai melewati batas pemikiran logis (kontra fakta). Kumpulan hasil analogi dalam proses pengelolaan menjadi pilar-pilar pembangun konsep yang ditemukannya. Maka pemetaan tersebut dipergunakan siswa dalam mengidentifikasi jenis cerita lainnya, baik pada jenis teks yang sama atau jenis teks yang berbeda. Hal tersebut yang dikatakan sebagai aktivitas belajar berbasis pada teks (materi yang dipelajarinya).

Perolehan dari pelaksanaan model tersebut dalam pembelajaran sastra, mengenai dasar penyebutan untuk teks sebagai cerita fantasi pada akvtivitas berikutnya berkedudukan sebagai intelegensi yang dapat mengenali ragam kontra fakta dapat berupa keajaiban yang lekat pada peristiwa cerita, keanehan yang lekat pada situasi sesuai dan tidak sesuai, kemisteriusan yang lekat pada aksi dalam cerita, dan akan ditemui pada setiap cerita fantasi, sehingga proses penemuan konsep akan melahirkan pernyataan "ciri umum cerita fantasi". Demikian pula halnya dengan temuan berupa data dan informasi yang terdapat pada cerita fantasi yang beranjak dari konsep bahwa cerita jenis tersebut memiliki unsur hiperbola, bertolak belakang, dan tidak sesuai realita. Maka analogi pada siswa mencapai temuan bahwa ide cerita dapat berupa hal nyata atau khayalan, latar dapat berupa penggabungan ruang dan waktu yang berbeda dari realita, bersifat fiktif. Dan tokoh-tokoh yang ada identik dengan identitas adanya keunikan seperti memiliki kesaktian, memiliki organ tubuh yang tidak umum, berasal dari tempat yang tidak pernah ada, dan dihadirkan dalam cerita dengan bahasa yang 


\section{Journal Indonesian Language Education and Literature Vol. 2, No. 2, 2017 \\ http://www.syekhnurjati.ac.id/jurnal/index.php/jeill/}

mampu memicu imajinasi, emosi, serta variasi bahasa yang ekspresif melalui percakapan-percakapan tokoh dalam cerita.

\section{Simpulan}

Berdasarkan penelitian yang telah dilakukan dapat disimpulkan bahwa penggunaan model alternatif dalam pembelajaran sastra sangat diperlukan. Terutama model yang memiliki tambahan dalam capaian tujuan belajar, yakni pada kemampuan menemukan konsep dan menentukan keputusan dalam bersikap secara sosial. Hasil penelitian diperoleh bahwa teks sastra realis dapat dimanfaatkan sebagai sumber atau bahan ajar. Pengembangan model ini berupa penemuan konsep dalam pembelajaran sastra di SMP. Penggunaan perangkat belajar (buku siswa dan buku guru) yang bersifat universal harus dilengkapi dengan aktivitas tambahan. Salah satunya melalui pengembangan aplikasi pembelajaran. Keberagaman situasi, kondisi, dan kemampuan siswa harus terlebih dahulu diarahkan pada satu persepsi. Hal ini dilakukan agar masing-masing kompetensi, karakteristik, dan kapasitas individu dapat menumbuhkan kemapanan keilmuan secara utuh. Oleh karena itu, pengajar, peneliti, dan pihak yang berkompeten disarankan untuk melakukan penggalian dan pengkajian lebih lanjut. Pengkajian itu terkait aktivitas dan perangkat pendukung pembelajaran.

\section{Daftar Pustaka}

Cunningsworth, A. 2008. Choosing your Coursebook (2nd ed.). Thailand: Macmillan Education.

Liliani, E. 2012. Mengurai Permasalahan Pembelajaran Sastra. Pengembangan profesionalisme guru bahasa dan Sastra Indonesia (pp. 160-167). Yogyakarta: Fakultas Bahasa dan Seni, Pendidikan Bahasa Indonesia.

Moleong, Lexy. J. 2010. Metode Penelitian Kualitatif. Edisi Revisi. Bandung: Remaja Rosdakarya.

Moos, Daniel C. dan Ringdal, Alyssa. 2012. "Self-Regulated Learning in the Classroom: A Literature Review on the Teacher's Roleh" dalam Education Research International, Volume 2012, Article ID 423284, halaman 1-15 http://dx.doi.org/10.1155/2012/423284 
Journal Indonesian Language Education and Literature Vol. 2, No. 2, 2017

http://www.syekhnurjati.ac.id/jurnal/index.php/jeill/

Peters, R. S. 2010. "The Conceptual of Education. In R. S. Peters (Ed.)" dalam International Library of The Philosophy of Education. 17, pp. 10-15. London: Routledge and Kegan Paul.

Simaremare, R. 2010. Problematika Bahan Ajar dalam Pembelajaran Sastra yang Berorientasi Pada Respon Pembaca. Medan: Sumatera Barat. 